\title{
Chapter 6 \\ The Temporary Nature of Ukrainian \\ Migration: Definitions, Determinants \\ and Consequences
}

\author{
Agata Górny and Marta Kindler
}

\subsection{Introduction}

Temporary and fluid forms of mobility have been growing in importance in recent years, with international migration becoming an increasingly complex process, difficult to define and measure. Notions of temporary and long-term (or settlement) migration are usually either over-fuzzy or too strict to capture various "in-between" types of mobility. Consequently, a number of short-term, circular or incomplete forms of migration are not being captured in research (Robertson 2014), and studies of the duration of temporary migration projects, such as those involving, for example, repeated trips to one country for years or for a lifetime, are rare (Stola 1997; Morokvasic 2004).

The circular migration framework has attracted the attention of policy makers in national and international contexts as a form of temporary mobility which can bring about "triple-win" outcomes - for migrants and for both destination and sending countries (see Vertovec 2007; Constant et al. 2013; EMN 2011). The positive view of this kind of mobility seems to echo earlier enthusiasm for temporary migrant workers' programmes (so-called guest-worker programmes).

Discovering the mechanisms of temporary mobility has become a high-priority task on the European political agenda. This means, however, that temporality has become a necessary analytical dimension in migration studies - not only the tem-

The original version of this chapter was revised. An erratum to this chapter can be found at DOI 10.1007/978-3-319-41776-9_14

Analyses presented in this chapter were partly funded by the National Science Centre under the research project: "Two decades of irregular temporariness? An examination of changes in mobility from Ukraine to Poland in a multidimensional perspective" (no. DEC-2011/B/HS4/02275)

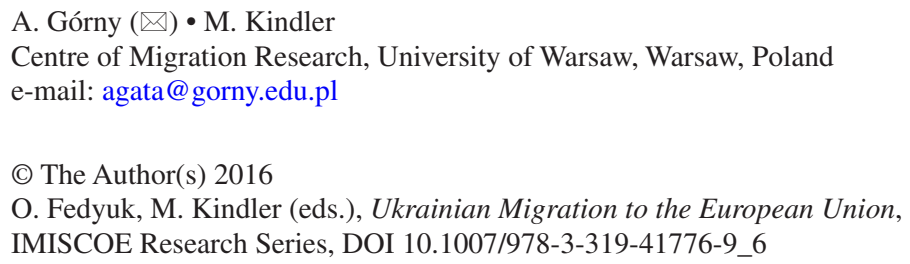


poral dimension of migration (duration of stays, etc.), but also its associated processes, such as the variety of causes and consequences of temporary and permanent mobility, adaptation strategies used by temporary and permanent migrants, and others. In other words, when migration understood as the time-space strategies of individuals is under consideration, "time" should be explored, not just as a length of stay, but as a meaningful sociological component, to a greater extent than is the case in traditional approaches devoted mainly to permanent migration.

Mobility can be understood broadly as migration and other more fluid types of movement. The relatively large scale of Ukrainian migration to Europe makes it a powerful case for addressing the above issues; the presence of Ukrainians in a number of European countries allows for cross-country comparisons with regard to temporal patterns of mobility; and, finally, Ukrainian migration takes a variety of forms, temporary and circular mobility being the most prevalent. In contrast to other thirdcountry nationals in Europe, especially those from geographically more distant countries, Ukrainian migrants remain largely mobile, especially those heading for Central Europe.

Last, but not least, in contrast to the "managed circularity" (via special programmes) promoted by politicians promising a "win-win-win" scenario (EMN 2011), Ukrainian migration is an example of a predominantly "spontaneous circular migration". Individual Ukrainian households bring about this mobility, using their limited resources, migrant networks and an industry of "mobility facilitators" (such as, for example, companies arranging travel documents). Meanwhile, as some authors advocate (Newland et al. 2008), understanding mechanisms of spontaneously developing circular migration is the most valuable insight into how this type of mobility should be managed. Lessons drawn from the study of Ukrainian migration can therefore contribute to the discussion on the role that temporary migration can play in the entry of third-country nationals to Europe and what the most effective solutions for its management are.

Temporariness of Ukrainian migration is, however, to a great extent determined (restricted) by visa regulations, which usually allow Ukrainians to enter and stay in the destination European countries only for a short time and without the right to work (see Chap. 4). Therefore, this chapter addresses constraints on permanent migration encountered by Ukrainian nationals coming to Europe. The analysis is not limited to the link between legal constraints and temporariness of migration, but also takes into account other aspects of mobility (employment opportunities, family situation, social resources and others), which are crucial in shaping the circular character of mobility (cf. Vertovec 2007).

Moreover, this chapter predominantly refers to studies carried out in Central and Eastern Europe (CEE), which are particularly numerous because Ukrainians constitute the main group of labour migrants in countries such as Poland and the Czech Republic. This is not the case in Western and Southern European countries, where Ukrainian nationals are one among many national migrant groups. Moreover, Ukrainian labour migrants in the CEE region are particularly likely to be involved in mobility of a highly temporal character (e.g. shuttle mobility). Thus, the topic of temporality of mobility is highly relevant to Ukrainian migration to these countries. 
The analysis begins with a short overview of migration literature, demonstrating how temporality (as an analytical dimension) and temporariness (as the characteristic of temporary migration) are addressed in migration literature generally, and locating works on Ukrainian migration to Europe within this literature. An examination of definitional issues allows a particular focus on notions used to analyze temporary migration from Ukraine. First, the main lines of research on temporary migration from Ukraine are discussed, focusing on definitional issues and examining notions used to analyze Ukrainians in particular. Second, we examine how the determinants of different temporal forms of mobility of Ukrainians - mainly temporary versus permanent migration - are considered, as addressed in the literature. Finally, the consequences of temporariness for Ukrainian migrants, as well as for destination countries are examined. We omit consequences for Ukraine as they have been addressed in detail in Chap. 3. In the conclusions we consider the results of our overview in the context of the "triple-win" scenario promoted in the political discourse on temporary migration in Europe. The approach in this chapter is determined, therefore, both by the themes identified in the literature and by the theoretical and practical relevance of the problems of immigration of third-country nationals to Europe.

\subsection{Theoretical and Empirical Aspects of Temporality and Temporariness}

\subsubsection{Temporality in Migration Studies}

Temporality, understood as the time dimension, though crucial, is one of many factors taken into account in definitions and categorizations of migrants and nonmigrants in migration literature. Others include the space dimension (direction of migration), the goal of migration and the political context. The secondary role of the temporal dimension in classic works on migration stems from the fact that these works were mainly devoted to overseas and international migration to Europe, usually with a tacit assumption that migration should involve a longer stay or settlement (cf. Massey 1999). Nevertheless, reflection on the temporality of migration or specifically on the differences between temporary and permanent mobility was not fully excluded from theoretical and empirical consideration as early as the 1970s and 1980s (cf. Zelinsky 1971; Burawoy 1976; Piore 1979, 1986; Stark and Bloom 1985; see also King et al. 2006; Cwerner 2001).

At the same time, several interesting perspectives on how to approach "time" in international mobility have been already proposed. As regards determinants of temporal patterns of migration, a classic work by Hägerstrand (1975) - his "time geography" - deserves attention. It analyzes decisions of migrants through the lenses of constraints and opportunities for pursuing a given time-space strategy (e.g. permanent migration versus temporary migration). Constraints are listed under three 
headings. The first are capacity constraints - the lack of physical, economic or social means to undertake certain actions. The second are coupling constraints - the inability of individuals to be engaged in various activities, such as creating a family, or to be in different locations at the same time. Some of these projects are tied to a place, while others can be easily transferred (Malmberg 1997). The third group of factors are steering constraints - rules and laws that limit or increase access to timespace. For example, Malmberg elaborates on Hägerstrand's framework of constraints on settlement migration by noting that the opportunities to migrate internally can explain the lack of incentive to migrate abroad (Malmberg 1997: 25).

More recent and less well known is an approach of Robertson (2014) who coined two time-related concepts that can be helpful in capturing the complexities of present-day migration trajectories: "time track" and "timescales". The first concept refers to "movement over time but not always forward movement" (2014: 4). Robertson argues that a migration time track does not have to be linear and can stop or restart at different moments of a migrant's life. In turn, she understands "timescales" as temporal ordering of various events at macro level (political and economic global and national contexts), meso level (migration regimes, systems of governance, institutions, brokers, agents) and micro level, encompassing life events in a migrant's biography. The openness of the "time track" concept can be perceived as both a strength and a weakness of the proposed approach; however, it enables the analysis of temporary mobility without predetermined concepts of migration such as circular migration, return migration, transnational migration and others.

The above approaches focus on the context of decisions about mobility strategies of individuals. It can be argued that a different perspective is taken by Cwerner (2001) in his "times of migration" approach. He sees temporality of mobility not only as its temporal form - various temporary forms of mobility versus permanent migration - but also as a development of migration experience in time both at the individual and group level. Consequently, he focuses on the temporal dimension of the incorporation of migrants into host societies while proposing eight types of "times" that intersect with behaviours of migrants at different stages of their migration experiences (cf. King et al. 2006). An important part of his argument relates to the significance of the temporal dimension in discussions not only on immigration but also on the nation-state and multicultural societies (Cwerner 2001).

\subsubsection{Temporariness of Mobility in Migration Studies}

Temporariness as a characteristic of temporary migration was first addressed in pioneering works on internal, urban-rural labour mobility in Africa that focused on circular mobility (e.g. Mitchell 1961; Elkan 1959; compare Kaczmarczyk 2002). The list of studies on temporary mobility that supplement earlier studies focusing on permanent migration is already substantial (see for example, Danzer and Dietz 2009; Ács 2010; Constant and Zimmermann 2011; EMN 2011; Constant et al. 2013). 
Four main concepts have been developed to capture the notion of temporary international movements: circular migration, return migration, transnational migration and - recently - liquid migration. The concept of "liquid migration" pertains to migration movements that involve "complex, transitory patterns in terms of transient settlement - transnational or otherwise - and shifting migration status" (Engbersen et al. 2010: 117). This approach to migration is gaining in importance in studies on mobility within the European Union, where lack of administrative borders allows migrants to freely change their destinations.

The remaining three research streams are more universal. Works on return migration concentrate first of all on the probability that migrants will return home at some point in their stay abroad and on how migration experience impacts intentions to return (cf. Dustman and Weiss 2007; Dustman and Kirchkamp 2002). It should be stressed, however, that there is no single definition of return migration in this field even though it is usually assumed that a return migrant is a person who leaves the destination country with the intention of remaining at home for a longer time. Studies of return migration from the perspective of the destination country focus on the departure from the destination country rather than on the migrant's intentions and duration of stay in the home country (Fihel and Górny 2013). Such a definitional approach intersects with the approach frequently encountered in studies on circular migration, which can be defined as "systematic and regular movement of migrants between their homelands and foreign countries typically seeking work" (Constant and Zimmermann 2011: 498).

Research on circular migration addresses a number of topics, but among the most frequent are determinants and patterns of migration, and selectivity in circular mobility with regard to different individual characteristics of migrants. The main conclusions of these works are that distinctive determinants of circular migration (as opposed to permanent migration) can be identified pertaining to individual characteristics of migrants and opportunity structures in sending and receiving countries. Circular migrants are more often men than women, possess vocational more often than secondary or higher education and have their households located in the sending country (cf. Constant et al. 2013).

Different emphases and research topics can be found in the literature on transnational migration. Levitt et al. (2003: 565) argue that transmigrants are those who maintain "enduring ties to their homelands even as they are incorporated into countries of settlement". Research on transmigration arose in response to methodological nationalism, as a framework where the perspective has moved away from the centrality of a single state.

In the review of literature on Ukrainian migration that follows, the Hägerstrand (1975) "time geography" approach is employed. This enables temporary mobility to be addressed from the perspective of the constraints on permanent migration. This also corresponds with the character of Ukrainian inflow to Europe governed by the legal regulations that limit opportunities for their settlement in Europe. Approaches and concepts used in the examination of Ukrainian migration are considered with a focus on three concepts developed in the literature: circular migration, return migration and transmigration. 


\subsection{Temporal Forms of Ukrainian Migration and Their Definitions}

How are intersections between the temporariness of Ukrainian mobility and its durability captured in the definitions and concepts used in works about Ukrainians migrating to Europe? The answer to this question requires us to distinguish between specific national and regional approaches in studies of Ukrainian migration. For example, researching Ukrainian migration to Spain, Hosnedlová and Stanek (2010, 2014) suggest that there are two migratory systems, one based on short-distance migration between Ukraine and the neighbouring countries of CEE and the other based on long-distance migration to Southern and Western Europe. According to the Spanish National Immigrant Survey of 2007, trips of Ukrainian migrants to their home country were infrequent and short: one-third of the surveyed migrants visited Ukraine less often than every 2 years (Hosnedlová and Stanek 2010; see also Chap. 12). Malynovska (2004) points to the differences in the duration of migration between the various destinations (in Poland and Germany the stay lasts between one and six months, while in the Southern European countries it is over 6 months). However, these authors have not proposed any particular time-related analytical notions to capture the observed regional variations in mobility of Ukrainian nationals.

One particular group of works, focusing on Ukrainian migration to the CEE region, deals with the early 1990s Ukrainian "shuttle movements" of cross-border traders to Poland, which were usually very short - lasting from a day to several days - and of a predominantly intensive circular character. A variety of terms were used to describe this particular mobility, such as "highly temporary", "transitory", "flexible", "circular", "pendulum" and "fluid" (Stola 1997; Okólski 1997, 2001, 2004). These notions reflect the specificities of mobility from and to the CEE countries in the 1990s which was not only the result of geographical proximity, but was also a period following political and economic transition in the region. At the same time, researchers analyzing this form of mobility pointed to the fact that although these flows of foreigners were non-permanent, they represented a stable number of foreign workers in the stock.

The concept of circular migration has been used particularly frequently in studies on Ukrainian migration to Central Europe - the Czech Republic, Hungary and Poland (Grzymała-Kazłowska and Okólski 2003; Górny et al. 2010a; Drbohlav 2003; Illés and Kinces 2012; see also Chap. 7). However, only certain works elaborate in greater depth on the conceptual issues pertaining to circular migration. Illés and Kincses (2012), researching immigration to Hungary, including the inflow of Ukrainians, proposed a statistical operationalization of circular migration capturing the repetitiveness (thus the time dimension) of mobility. They defined international circular migration as "a hetero-space and discrete-time spatial mobility system containing at least three interlinked individual moves in which two have return character" (2012:203). On the basis of this definition, the authors used official registries to argue that circular migrants accounted for around $15 \%$ of all migrants coming to 
Hungary between 2006 and 2008. The same study also showed that circulation to Hungary is typical for Serbians, Romanians and Ukrainians and is observed primarily in border regions. It is arguable whether three movements already amount to circular migration. The other question is whether official registries enable circular movements to be captured adequately. The authors admit that their study covered only officially defined migrations which lasted for 1 year or longer. Consequently, all shorter trips to Hungary were ignored. It should be stressed that even if registries include shorter migrations (but usually not longer than 3 months), the problem of neglecting some part of circular mobility not captured in official registries usually remains.

Other elaborations on the character of circular migration can be found in works on Ukrainian migration to Poland that discuss not only cross-border traders but also economic short-term migrants. Okólski (1997, 2001) proposed the concept of "incomplete migration" to describe this circular flow of migrants. Okólski draws on Chapman and Prothero's (1983-1984) definition of a "territorial division of responsibilities, activities and goods", with people linked to a pendulum, having no clear intention of a long-term change of dwelling (Okólski 2001: 56). He classified as "incomplete migrants" those spending most of the year in the country of migration, and for whom the income earned abroad constituted an important part of the overall household income in the country of origin. Incomplete migration is characterized by circulation and work in the secondary labour market. According to the results of one of the earliest studies on Ukrainian migrants, an ethno-survey carried out in three localities in Ukraine between 1993 and 1996, the average length of Ukrainian migrants' stay in Poland was between 2 and 3 weeks (Okólski 2001). The study identified three major strategies characterizing incomplete migrants from Ukraine to Poland: migration as a physical survival strategy (for households with income below subsistence level and those where none of the members worked); migration as a transformation-period survival strategy (attempting to preserve the previously acceptable living standards and diversifying the sources of household income); and migration as an entrepreneurial strategy, with the goal of creating or developing one's own business (ibid.). The concept was used not only to analyze Ukrainian migration to Poland, but also Polish migration to Western European countries (Jaźwińska and Okólski 1996, 2001) in the 1990s. However, its usage is limited in later migration studies, because the incomplete migration approach is embedded in the context of the post-communist economy and has not been further developed to accommodate the transition towards a market economy in CEE countries.

As in the above overview of Ukrainian incomplete migrants' strategies, the role of a household's place of residence in conceptualizing migration was also stressed in the typology of mobility proposed by Górny et al. (2010b) for immigration to Poland. The study was based on 160 qualitative interviews (including 75 interviews with Ukrainian migrants) conducted in different studies in $2005-08$ by the Centre of Migration Research, University of Warsaw. The typology was based on two dimensions: (1) whether a migrant lives in Poland (operationalized by the presence of other household members and the duration of stay); and (2) the number of countries in which a migrant lives. The proposed categories include "immigrant" (living 
basically in Poland), "circular migrant", "transmigrant" (connected to Poland) and a rather theoretical category of "transmigrants" (not connected with Poland, i.e. living in several countries but not in Poland). Two of these categories relate in particular to temporary mobility. "Circular migrants" have been defined as those who come regularly to Poland but who regard their home as being in another country (usually the home country), whereas "transmigrants (tied to Poland)" are those whose place of residence is in Poland and in one or several other countries (Górny et al. 2010b: 191-192).

Results of this study suggest that "circular migrants" originated originally from the ex-USSR (mainly Ukraine) and typically worked in secondary market sectors such as domestic services and construction. They also had a tendency to operate in the social circles of other circulants and were relatively likely to attract new circular migrants to Poland. "Transmigrants" were more diversified in terms of sector of employment and character of their social ties in Poland than "circular migrants." It should be stressed, however, that, according to the results of this study, transmigration was usually a transitory stage leading to more permanent forms of migration in Poland or presumably abandonment of migration to Poland (which could not be analyzed in the study described). In contrast, circular migration was found to be a relatively durable pattern of migration.

The above approach links circular migration with transmigration, a connection not often noted in the literature on Ukrainian migration to Central Europe. The study suggests, however, that Ukrainian migrants coming to Poland should be seen rather as circular migrants and to a lesser extent as transmigrants. Other studies conducted in CEE employ the notion of transnationalism, usually to analyze the degree of integration of Ukrainians in the host society. For example, GrzymałaKazłowska and Okólski (2003) argued that, even though the most prevalent adaptation strategies among Ukrainian migrants in Poland in the 1990s were "surface accommodation", typical of short-term and circular migrants, and "assimilation", the formation of "transnational social spaces" in which migrants operated was also relatively frequent. Consequently, even those who were settled in Poland were capable not only of maintaining close contact with their friends and relatives in Ukraine, but of actually being simultaneously members of both societies (GrzymałaKazłowska and Okólski 2003).

The notion of circulation is rarely found in studies in European countries outside the CEE region. However, it has been used by some scholars analyzing temporary forms of Ukrainian migration to Italy (Vianello 2011, 2013; Solari 2010; see also Chap. 10). For example, Vianello (2013) developed, on the basis of a qualitative study, a typology related to the circulation of Ukrainians to Italy. The two main dimensions that she uses are the place of residence of the migrant's family (Ukraine vs. Italy) and gender combined with the age of migrants (adult women, adult men and a third category of young second-generation migrants). This typology, like that of Górny et al. (2010a, b), suggests that the presence of family in the country of origin or the country of destination is one of the identifiers of circulation. Overall, this typology, although stimulating, can be considered as descriptive rather than as providing actual ideal types and is thus difficult to apply in other studies. 
Apart from developing a rich definitional framework to analyze the circularity of Ukrainian migrants to Italy, Vianello (2013) points also to a transnational "double presence" of migrants, who engage in transnational practices to cultivate family ties in Ukraine. These practices enable Ukrainian women to perform roles related to their multiple identities, not only as workers, but also as mothers and grandmothers. This "double presence", which Vianello refers to also as "the migrant in transit" (see Chap. 10), also demonstrates the durability of temporary forms of mobility, creating a transnational social space within which repetitive movements continuously occur.

Summarizing, among the concepts that have been most frequently used in the analysis of Ukrainian migration to Europe are circular migration and transmigration (or transnational practices). We can talk about some "national/regional approaches" as regards the usage of these two terms. Studies on Ukrainian migration in CEE usually refer to circular migration, while research in Southern Europe discusses, rather, transmigration or transnational activities. The term "return migration" has been much less popular in studies of Ukrainians in Europe presumably because the return movements to Ukraine are typically short visits and do not relate to intention to return as suggested by studies both in Central and Southern Europe.

More nuanced approaches to these migration concepts can be also found in the literature reviewed here. Time dimensions addressed in them include, for example, duration of stays in the home and destination countries, and number (intensity) of trips. These approaches usually take the form of empirical-only typologies proposing some specific diversifications of types of circular and/or transnational migrants coming to the given country (cf. Górny et al. 2010b; Illés and Kinces 2012; Okólski 2001; Vianello 2013). What they virtually all have in common is an emphasis on the role of a household and its location (country of origin or migration) in determining patterns of mobility. However, novel terms introduced by researchers to capture temporariness in Ukrainian migration, even if defined, are difficult to operationalize, and thus their use is rather limited.

\subsection{Determinants of Ukrainians' Temporary Mobility}

The discussion on the determinants of temporary aspects of Ukrainian migration starts by examining research on steering constraints (cf. Hägerstrand 1975), such as laws and regulations on entry and stay, and restrictions on labour market participation (see Chap. 4). These constraints are usually to the fore when temporal patterns of Ukrainian migration are discussed. However, as the literature research suggests, other factors should also be acknowledged in this respect. They can be demonstrated within the framework of the capacity constraints (mainly insufficient social resources useful during migration) and coupling constraints (predominantly those related to family obligations). 


\subsubsection{Steering Constraints - Legal and Economic Context of Temporary Mobility}

For cross-border migration to take place in general, and for temporary forms of migration in particular, the necessary condition of being able to leave the home country without being prosecuted has to be met. For this reason, researchers usually regard the relaxation of the exit regulations introduced in the early 1990s in Ukraine as a crucial factor encouraging temporary mobility of Ukrainian nationals (Malynovska 2004; Okólski 2004; Stola 1997, 2001; Wallace 2002). The current exit regulations give Ukrainian nationals not only the right to travel abroad, but also to return after having migrated, which had not previously been the case before the political reforms of the early 1990s (see also Chaps. 2, 4 and 8).

Studies of Ukrainian migration also demonstrate the importance of entry policies (visa regimes) in shaping temporal mobility patterns. For example, according to Iglicka et al. (2011: 16), circulation between Ukraine and Poland has been "forced by procedures operating within short-term visa systems". After the introduction of visas for Ukrainians in Poland in 2003, Ukrainian migrants still tended to enter Poland on short-term visas, but the changed legal framework for migration introduced the so-called "time corridor", which forced the migrants to remain in Ukraine for at least three out of every 6 months (Follis 2012; Kindler 2011; see also Chaps. 4 and 7). The role of differences in entry policies between European countries in shaping Ukrainian movement to the European Union can be also traced. For example, Dietz (2010) demonstrated that when Germany relaxed visa procedures for Ukrainians in 2000, a number of Ukrainians entered Germany, only to travel onwards to the Netherlands and Portugal.

Studies on the migration of Ukrainians to Southern Europe have emphasized the role of regularization regimes, characteristic of the Mediterranean migratory model, in shaping temporal patterns of mobility (see Chaps. 4, 11 and 12). In the 1990s Wallace (2001) drew attention to a unique institutional factor determining circulation between Ukraine and Central Europe that can be also considered as a steering constraint: limited access to the welfare state. She argued that the employment/ contribution-based welfare system in the destination countries along with the irregular status of migrants determine migrants' need to stay in contact with their own welfare system, to be entitled to health care and pensions. There are hardly any studies analyzing the impact on temporal migration of the existence (or lack) of social security agreements between Ukraine and migrant-receiving countries (European Migration Network 2011).

In addition to entry policies, labour policy and programmes can play an important role in shaping temporal patterns of mobility. For example, according to a study by Janska and Drbohlav (2008), one factor in the changing temporal patterns of Ukrainian migration to the Czech Republic was the introduction of a pilot project by the Czech government aimed at attracting qualified foreign workers to settle. Since January 2006 Ukrainians have been eligible for this scheme and in 2007 they were the second most numerous national group, at $18 \%$ of applicants. In contrast, 
studies conducted in Poland demonstrate how labour policy regulations can also induce temporariness and shape its temporal pattern. The introduction of regulations facilitating access to the labour market for neighbouring countries' citizens (including Ukraine) in Poland created a channel for the official inflow of seasonal migrant workers to Poland, reinforcing the temporariness of labour migration from Ukraine to Poland (Brunarska 2014; for more details on the system of declarations see Chap. 4).

Similar outcomes have been observed in the case of Ukrainian migration to Italy, when the 2007 labour agreement introduced "the possibility of job sharing, an important new opportunity that has significantly encouraged circular migratory practices" (Vianello 2013: 198). Under this agreement, foreign workers were legally entitled to share their job responsibilities with another person and manage their schedule independently of employers. Migrant women began to organize their work in Italy in 3-to-6-month shifts.

Studies on determinants of Ukrainian migration frequently cite failed economic reforms and falling wages resulting in deteriorating living standards in Ukraine as one of the main motivations for engaging in temporary labour migration. According to one study, the majority of Ukrainian migrants in Poland claimed that only improvement in the economic situation in Ukraine - meaning higher earnings and less corruption - would make them consider ceasing to circulate in this way (Górny et al. 2013). The dissatisfaction with pay rates (or income) also raised the odds of engaging in temporary labour migration (see Chap. 3). According to the results of qualitative research carried out between 2005 and 2008 the limited chances of finding well-paid employment in Ukraine stimulate the durability of circulation among the Ukrainian female migrants studied in Italy (Vianello 2013).

Research in Poland demonstrated that the existence of informal labour and job markets in the destination country is conducive to circular and temporary migration (Iglicka 1999; Szulecka 2007) since undeclared work is usually associated with insecure employment, which does not create favourable conditions for long-term stays and settlement (Gmaj 2005). The latter can be also observed in the frequently analyzed example of domestic workers employed for care work and cleaning. The nature of their work does not encourage settlement, as claimed by various authors, since the sector is dominated by undeclared work and characterized by low pay and low status (Kindler 2008, 2011; Kindler et al. 2015; Kordasiewicz 2010; Kordasiewicz 2011).

Another theme distinguished in the literature is the impact of the labour market requirements of the destination country, where jobs in the various sectors with a demand for foreign labour have particular temporal characteristics. For example, studies on Ukrainians coming to Poland in the 1990s confirm that stays of petty traders in Poland were noticeably shorter, lasting sometimes only several days or weeks, compared with those of migrants engaged in seasonal work in agriculture, for example, who spent up to 3 months in Poland (Stola 1997; Iglicka 1999; Okólski 1997; see also Chap. 8). 


\subsubsection{Capacity and Coupling Constraints: Social Resources (Networks) and Family Situation}

Iglicka and Gmaj, discussing the length of stays and return of Ukrainian migrants in Poland, claim that "circularity is often a result of the passive attitude of human nature. Immigrants tend to follow well-established patterns created by their networks" (2013: 173). According to qualitative studies, limited initial access to migrant networks (lack of formal migrant services) is an important capacity constraint for Ukrainians who want to engage in long-term migration to more distant EU destinations than Poland or the Czech Republic (Kindler 2011). In the absence of such networks, not only are information and potential ties to people who may lend money for long-distance (possibly more expensive) travel missing, but ties to those who can provide support on the spot are also lacking. Fonseca et al. (2014) attribute the significant decrease that has been observed in the inflow of Ukrainians to Portugal since the 2008 economic crisis to the changing role of migrant social networks (see also Chap. 11). These networks, which provided positive feedback on job opportunities and assistance to newly arrived migrants, have started to transmit information about the decline in job opportunities in Portugal.

In nearby destinations for Ukrainian migrants such as Poland, the role of social networks in forming capacity constraints has also been observed. Kindler (2011), in a qualitative study of Ukrainian migrant domestic workers in Warsaw, points out that migrants with limited access to social networks and information had to accept very poor (if not exploitative) working conditions which did not encourage them to consider settling in Poland. Moreover, Górny et al. (2010b) argue, based on the rich qualitative material on immigration to Poland, that the social networks of circular migrants enable them first and foremost to continue circular migration. Ukrainian circular migrants can only transform their circular mobility into long-term forms of migration when they manage to develop social relations outside their own group (i.e. other circular migrants) and when these new contacts provide them with resources to pursue a different model of mobility (Górny et al. 2010a, b).

In line with these observations, Toruńczyk-Ruiz (2014), who also studied networks of circular migrants travelling from Ukraine to Poland, found that "ties based on work relationships and those helpful in finding a job seem to be stronger and more important than social ties maintained in the place of residence in Poland" (2014:56). This suggests that temporary stays in Poland rarely lead to Ukrainian migrants developing local ties that could result in stronger attachment in Poland and in a higher propensity towards settlement. Toruńczyk-Ruiz (2014) also found that those who had mainly formed ties (with Poles) in their neighbourhood in Poland more closely resemble long-term migrants than circular migrants and are more oriented towards the receiving society.

The role of family situation in shaping temporal patterns of migration is significant. The studies reviewed here frequently address the role of family in determining the temporal character of Ukrainian migration from one of two perspectives: location of family members (remaining in Ukraine or/and in destination country); and 
marital status (with a special focus on divorced women and women married to nationals of the destination country). In particular, a number of studies analyze the impact on temporal mobility patterns of migrant family members' presence in the country of origin (Hosnedlová and Stanek 2014; Tolstokorova 2010). They argue that having at least one immediate family member in Ukraine indicates strong ties with the place of origin and may influence the decision to return, thus inducing temporariness of migration. While the authors did not verify this claim empirically, Hosnedlová and Stanek (2010, 2014) demonstrated that in Spain, 35.4\% of Ukrainian migrants had at least one family member in Ukraine or elsewhere, and most Ukrainian women without a husband with them in Spain formed transnational families (see also Chap. 12). Näre (2007), focusing on female Ukrainian migrants in Italy, also found migrant women's marital status played an important role in the decision to engage in temporary/circular forms of mobility. The women Näre studied were divorced and in their early forties and were also the only breadwinners, which tend to raise the odds of engagement in temporary migration, as argued by Näre (see also Chap. 10).

The family dimension in Ukrainian migration to the EU strongly intersects with existing gender ideologies in the household and in society. In other words, Ukrainian women tend to have a subordinate position to men in the family hierarchy, as well as different caring responsibilities, and thus their temporal and spatial mobility strategies differ. In Spain, the proportion of men whose spouse or partner and at least one of whose children are living in their place of origin is four times greater than the proportion of women in the same family situation (Hosnedlová and Stanek 2010). Iglicka et al. (2011:16) argue that in "the Polish-Ukrainian case, circularity seems to be a female domain. Among other economic reasons, women who are engaged in circular mobility do not want to disappear from family life for good". At the same time, the authors stress that this "traditional" division of gender roles, in contrast, allows Ukrainian men, who are viewed as the main breadwinners, to prolong their stays abroad without the strong social labelling as bad parents or spouses which migrating women usually experience. Such observations are supported by a 2001 Ukrainian State Statistics Committee study demonstrating that even though female migrants accounted for $35.4 \%$ of all surveyed labour migrants, their share in "shuttle" or "suitcase" migration (also called petty-trade migration) was over a half (cf. Molodikova 2008). However, Molodikova (2008), who mainly cites the Italian study, argues that employment of women in domestic services, which is frequently irregular, results in their longer stays outside Ukraine than Ukrainian male migrants employed mainly in seasonal sectors (such as construction). This observation suggests that the assumption that women, as the main care providers, will want to return more often than men to their households/families and are consequently more likely to engage in circulation than men (see Iglicka et al. 2011) should not be taken for granted (see Chap. 5).

Some studies, though not numerous, also address the role of family in the process of converting temporary mobility into more permanent forms of migration. Authors researching Ukrainian migration to Southern Europe report that the presence of migrants' family members in the destination country is frequent, which may 
mean a reduction in temporary mobility. According to Hosnedlová and Stanek (2010, 2014; Chapter 12), 44.5\% of Ukrainian migrants had families in Spain and $33.7 \%$ brought all their children to Spain. Fonseca et al. (2014; Chapter 11) also quote studies demonstrating that $29.9 \%$ of Ukrainian migrants have migrated to Portugal to join one of their parents.

Where the settlement policy is relatively restrictive - which is the case in Poland - for many Ukrainian temporary migrants, marrying a Pole has been an opportunity to acquire legal residence status in Poland and to settle (Górny and Kępińska 2004; Brzozowska and Grzymała-Kazłowska 2014; see also Chap. 7). Thus, the studies under review suggest (though the evidence is not very robust) that reunification processes and family formation have played an important role in the settlement of temporary Ukrainian migrants in destination countries.

\subsection{Consequences of Ukrainians' Temporary Mobility}

Temporary mobility, especially of the circular kind, is being advocated as a possible solution to many of the challenges surrounding migration today. However, are there really effective "wins" for all stakeholders: migrants, sending and destination countries? This section carefully examines the positive and negative impacts of the prevailing temporary nature of Ukrainian mobility to Europe identified in the literature under review. The outcomes of various temporary forms of Ukrainian migration are addressed in relation to two groups of actors involved in the migration process migrants and destination countries. The outcomes of temporary and more long-term migration for the sending country - Ukraine - concern the following: depopulation, decrease of labour force, risk of brain drain, limited potential of remittances and return migration to stimulate the development of the Ukrainian economy (see also Chap. 3).

\subsubsection{Impact on Migrants/Households}

Overall, studies point out that temporary migrants are keener to send remittances than are permanent/long-term migrants (Buch and Kuckulenz 2004; Mansoor and Quillin 2006; Glytsos 1997). In the case of temporary Ukrainian migrants, providing financial support to their families is in general the main goal of migration and a clear outcome. ${ }^{1}$ The studies reviewed here usually find that remittances sent by temporary migrants are mainly spent on everyday consumption (Kindler 2011; Triandafyllidou 2011, 2013; UCSR and Ukrstat 2009; Chap. 3).

\footnotetext{
${ }^{1}$ As Grotte (2012) cites the data of the National Bank of Ukraine, in 2011 Ukrainian migrants transferred 7 million USD (4.3\% of Ukraine's GDP).
} 
The fact that Ukrainian migrants can transfer the money earned abroad personally without having to bear additional transfer costs is an advantage of temporary, especially circular, migration (Grotte 2012). However, qualitative studies on the remitting behaviour of Ukrainian migrants report negative examples of Ukrainian migrants being robbed on the way back to or upon arrival in Ukraine (Grotte 2012; Kindler 2011).

A study conducted in Italy (Weber 2004) indicates that difficulty in re-negotiating social status when back in Ukraine may constitute a constraint on return, and rather a motivation to remain abroad longer than initially intended, going home only for short periods of time. This shows that the "status tensions" experienced by temporary migrants, as well as by their children, are strongly linked to their statuses in their countries of origin, which can impact not only temporal patterns of mobility but also the well-being of both migrants and their families. This also demonstrates that lowprestige work in the destination country does deprive migrants of their social status, partially challenging the claim put forward, for example, by the dual labour market theory of Piore (1979) that such deprivation should be lower or non-existent in the case of temporary migrants. This is due to the fact that the Ukrainian migrants studied had experienced tensions about their social position in the country of origin.

The risk of deskilling or de-qualification is high for temporary Ukrainian migrants (see Triandafyllidou 2011; Caglar et al. 2011; Iglicka et al. 2011). The temporary migration of Ukrainian citizens is often related to temporary jobs that do not require high skills and belong to the so-called secondary sector of the labour market. Consequently, studies in a number of countries have found loss of skills among educated Ukrainian migrants performing low-skilled jobs (Antoniewski and Koryś 2002; Shakhno and Pool 2005; Fedyuk 2012). For example, a study based on two national surveys of foreigners in the Czech Republic provides evidence of a significant waste of human capital among Ukrainians (Leontiyeva 2014; see also Chap. 8). A crucial finding of this study is that migrants "with permanent residence permits turned out to be twice as likely to have skilled jobs compared to those with temporary residence permits and were half as likely to end up on the bottom rungs of the labour market" (Leontiyeva 2014:74). This suggests that the temporal dimension of migration, related to legal status on the Czech labour market, intersects with the risk of deskilling among migrants, which tends to be higher for temporary migrants.

Irregular stay means higher risks and consequently higher mobility costs between Ukraine and the country of migration (see Chap. 4). However, paradoxically, efforts to gain legal status, even temporary, or to take part in seasonal migrant worker programmes, may lead to negative financial and other consequences for migrants.

\subsubsection{Impact on Destination Country}

Triandafyllidou (2011), who studied Ukrainian, Albanian and Moroccan circular migrants, critically reflects on the benefits of circular migration for the country of destination, such as responding better to changing labour market demand and 
imposing very limited integration burdens. Such ideal benefits from circulation for the destination countries are in her opinion possible only if "EU member states make sure that their legal entry channels are simple and fast, so that migrant workers can satisfy the demands of domestic labour markets in several sectors where shortages are identified" (2011:10).

However, both quantitative and qualitative studies carried out in Poland and Hungary stress the positive outcomes of Ukrainian circular migration. In Poland temporary Ukrainian labour migrants complement the native workforce, filling market niches (see for example, Grabowska-Lusińska and Żylicz 2008; GrabowskaLusińska et al. 2010; Górny et al. 2010b; Chap. 7). Researchers analyzing Ukrainian circular migration to Hungary underline its positive aspects in terms of migrants' economic activity in the face of Hungary's ageing population (Kincses and Rédei 2009). In contrast, studies on Ukrainian, Albanian and Moroccan circular migrants in Italy and Spain (Triandafyllidou 2011: 5), illustrate the negative side of circular migration by stressing that longer absence of migrants from work in the destination country (while they visit the home country) is negatively valued by the employers, as they "want reliable, stable, year-round migrant workers".

Other negative aspects of Ukrainian temporary migration to Europe are often linked in the literature to irregularity, with irregular status becoming a major concern for receiving countries which not only lose out in terms of their national budget (undeclared work of migrants) and the additional costs of control and detention but also have to somehow address the issue of a group at risk of exploitation and marginalization (see Malynovska 2011). Moreover, it has been stressed in the literature that Ukrainian temporary migration, especially when the secondary sector of the labour market is involved, reproduces social, ethnic and gender inequalities (Fedyuk 2012, 2015; Tolstokorova 2010).

\subsection{Conclusions}

Ukrainian movements to Europe are not easy to capture using "traditional" definitions of migration. Researchers working in this field tend to propose various terms that draw attention to the durability of temporary forms of Ukrainian mobility. However, most works on Ukrainian migration report on circular and transnational migration (more specifically transnational practices), with little attention paid to the return migration perspective.

The literature reviewed here includes a considerable amount of the two former lines of research. However, the focus on migratory patterns, with the more frequent use of the term "circulation", is arguably more popular in studies on mobility to Central Europe, whereas a transnational approach is more evident in studies of more distant migration of Ukrainians to countries like Italy and Spain. In the latter studies the notion of return migration is also sometimes employed, and here the determinants of temporary forms of migration are first of all addressed. Such variations can be explained by the differences in temporal patterns of migration to nearby Central 
European countries and more distant countries of Europe. These differences deserve more in-depth comparative consideration, which could pave the way for a comprehensive conceptual framework to study temporalities in international mobility.

Given the prevalence of irregular work in "spontaneous circular migration" of Ukrainian nationals to Europe and other negative consequences of their temporary mobility, the literature reviewed in this chapter challenges the "triple-win scenario" promoted in political discourse on temporary migration in Europe. Although irregularity of work can be partly eliminated by the introduction of adequate programmes for seasonal and circular migration, other negative consequences of temporariness may still remain. These include deskilling and precarious work status, which both arise from the fact that temporary migrants are usually employed in the secondary sector of the labour market in the receiving countries. These negative outcomes would be difficult to eliminate even with the introduction of special programmes for temporary migrants. This is well illustrated by the case of Polish migrants who, even after gaining unrestricted access to the European labour market after Poland's accession to the European Union (though after some transition period in selected countries) are still being employed in low-skilled positions (Trevena 2013). ${ }^{2}$

In a number of studies on Ukrainian labour migrants to the EU the role of the migrant household is stressed. While according to approaches such as the New Economics of Labour Migration, income from migration is only one of many sources of household income (see Stark and Bloom 1985), households of Ukrainian migrants can hardly be said to engage in a risk-diversification strategy through migration. Instead, they become, as migration continues, increasingly dependent on remittances. This leads to "petrification" of temporary forms of mobility. Relations of a migrant with his/her household can thus act as a crucial determinant of temporary migration, but temporary migration poses important consequences for the functioning of a migrant household. It is difficult to assess whether this multifaceted relationship can be treated as a universal feature of temporary forms of mobility or whether it is specific to Ukrainian movements.

The literature on Ukrainian mobility can contribute to understanding the importance of the temporal dimension in migration studies. Works on the determinants of temporary aspects of Ukrainian mobility are the most numerous and provide the richest material for further studies. Analyses of legal, family and social determinants and consequences show clear differences between temporary, short-term and long-term (settlement) mobility. Research on economic factors, however, tends to treat the temporariness of Ukrainian migration as a given. In this field additional research addressing the temporal dimension of Ukrainian mobility in more depth is recommended.

Other topics under-studied in the reviewed literature include theoretical and empirical consideration of the role of institutions in structuring temporary forms of migration, in particular the role of employment agencies. A focus on their role in Ukrainian migration to Southern and Northern European countries would certainly

\footnotetext{
${ }^{2}$ British LFS (Labour Force Survey) (2014) http://discover.ukdataservice.ac.uk/series/?sn=2000026
} 
contribute to our understanding of migrants' agency in the context of limited legal channels of entry, stay and work.

\section{References}

Ács, V. (2010). Temporary and circular migration: Empirical evidence, current policy practice and future options in Hungary. Budapest: European Migration Network Hungary.

Antoniewski, R., \& Koryś, I. (2002). Imigranci o nieuregulowanym statusie: społeczne i ekonomiczne determinanty funkcjonowania w Polsce [Irregular migrants: Socio-economic aspects of functioning in Poland]. CMR Working Papers 47. Warsaw: Institute for Social Studies, University of Warsaw.

Brunarska, Z. (2014). Ukraińscy migranci zarobkowi w Polsce - dlaczego tak trudno ich policzyć? [Ukrainian labour migrants in Poland - why is it difficult to count them?] Studia BAS, 40(4): 155-174.

Brzozowska, A., \& Grzymała-Kazłowska, A. (2014). Procesy inkluzji migrantów a więzi i sieci społeczne wśród małżeństw mieszanych. [The proces of inclusion of migrants versus ties and social networks of mixed marriages]. Acta Universitatits Lodziensis. Folia Sociologica, 50, 69-87.

Buch, C., \& Kuckulenz, A. (2004). Workers' remittances and capital flows to developing countries. In ZEW Discussion Paper no 04-31.

Burawoy, M. (1976). The functions and reproduction of migrant labor: Comparative material from Southern Africa and the United States. American Journal of Sociology, 81(5), 1050-1087.

Çađlar, A., Sillo, T., Józwiak, I., \& Hires-László, K. (2011). Circular migration patterns migration between Ukraine and Hungary. Metoikos Project, European University Institute, Robert Schuman Centre for Advanced Studies, San Domenico di Fiesole.

Chapman, M., \& Prothero, M. R. (1983-1984). Themes on circulation in the Third World. International Migration Review, 17(4), 597-632.

Constant, A. F., \& Zimmermann, K. F. (2011). Circular and repeat migration: Counts of exits and years away from the host country. Population Research and Policy Review, 30(4), 495-515.

Constant, A. F., Nottmeyer, O., \& Zimmerman, K. F. (2013). The economics of circular migration. In A. F. Constant \& K. F. Zimmerman (Eds.), International handbook on the economics of migration (pp. 55-74). Cheltenham/Northampton: Edward Elgar.

Cwerner, S. B. (2001). The times of migration. Journal of Ethnic and Migration Studies, 27(1), 7-36.

Danzer, A. M., \& Dietz, B. (2009). Temporary labour migration and welfare at the New European Fringe: A comparison of five eastern European countries (IZA Discussion Paper 4142). Bonn: IZA.

Dietz, B. (2010). Migration from Ukraine: A challenge for the European Union? In M. I. Baganha, J. C. Marques, \& P. Góis (Eds.), Imigraçăo ucraniana: a emergęncia de uma ou várias comunidades? (pp. 187-210). Lisboa: Alto Comissariado para a Imigraçăo e Diálogo.

Drbohlav, D. (2003). Immigration and the Czech Republic (with a Special Focus on the Foreign Labor Force). International Migration Review, 37(1), 194-224.

Dustman, C., \& Kirchkamp, O. (2002). The optimal duration and activity choice after re-migration. Journal of Development Economics, 67, 351-372.

Dustman, C., \& Weiss, Y. (2007). Return migration: Theory and empirical evidence for the UK. British Journal of Industrial Relations, 2(45), 236-256.

Elkan, W. (1959). Migrant labor in Africa: An economist's approach. American Economic Review, 49(2), 188-197.

Engbersen, G., Snel, E., \& De Boom, J. (2010). A van full of Poles: liquid migration in Eastern and Central European countries. In R. Black, G. Engbersen, M. Okólski, \& C. Panţ̂ru (Eds.), A 
continent moving west? EU enlargement and labour migration from Central and Eastern Europe (pp. 115-140). Amsterdam: Amsterdam University Press.

European Migration Network. (2011). Temporary and circular migration: Empirical evidence, current policy practice and future options in EU member states. Luxembourg: Publications Office of the European Union.

Fedyuk, O. (2012). Images of transnational motherhood: The role of photographs in measuring time and maintaining connections between Ukraine and Italy. Journal of Ethnic and Migration Studies, 38(2), 279-300.

Fedyuk, O. (2015). Growing up with migration: Shifting roles and responsibilities within the transnational families of Ukrainian care-workers in Italy. In: M. Kontos \& G. Tibe Bonifacio (Eds.), In the dark: Family rights and migrant domestic work. Submitted for publication, under contract with Palgrave.

Fihel, A., \& Górny, A. (2013). To settle or to leave again? Patterns of return migration to Poland during the transition period. Central and Eastern European Migration Review, 2(1), 55-76.

Follis, S. K. (2012). Building fortress Europe. The Polish-Ukrainian frontier. Philadelphia: University of Pennsylvania Press.

Fonseca, M. L., Pereira, S., \& Esteves, A. (2014). Migration of Ukrainian Nationals to Portugal: Changing flows and the critical role of social networks. Central and Eastern European Migration Review, 3(1), 115-130.

Glytsos, N. P. (1997). Remitting behaviour of "Temporary" and "Permanent" migrants: The case of Greeks in Germany and Australia. Labour, 11(3), 409-435.

Gmaj, K. (2005). Imigranci na polskim rynku pracy w świetle opinii pracodawców [Immigrants on the Polish labour market in employers' opinions].Warsaw: Centre for International Relations.

Górny, A., \& Kępińska, E. (2004). Mixed marriages in migration from the Ukraine to Poland. Journal of Ethnic and Migration Studies, 30(2), 353-372.

Górny, A., Grabowska-Lusińska, I., Lesińska, M., \& Okólski, M. (Eds.). (2010a). Immigration to Poland: Policy, employment, integration. Warsaw: Wydawnictwo Naukowe Scholar.

Górny, A., Kindler, M, Piekut, A., Stefańska, R., \& Szulecka, M. (2010b). Wybrane aspekty integracji imigrantów: w poszukiwaniu mechanizmów sprzyjających dalszemu napływowi cudzoziemców do Polski [Selected aspects of imigrant integration: Searching for mechanisms supporting further inflow of foreigners to Poland]. In A. Górny, I. Grabowska-Lusińska, M. Lesińska \& M. Okólski (Eds.), Transformacja nieoczywista. Polska jako kraj imigracji [Unclear transformation. Poland as an immigration country] (pp. 188-231). Warszawa: Wydawnictwa Uniwersytetu Warszawskiego.

Górny, A., Kaczmarczyk, P., Napierała, J., \& Toruńczyk-Ruiz, S. (2013). Raport z badania imigrantów w Polsce [Report from research on immigrants in Poland]. Warszawa: Fundacja Ośrodek Badań nad Migracjami.

Grabowska-Lusińska, I., \& Żylicz, A. (2008). Czy polska gospodarka potrzebuje cudzoziemców? [Does the Polish economy need foreigners?]. Warsaw: Centre for Migration Research, University of Warsaw.

Grabowska- Lusińska, I., Anacka, M., Janicka, A., Kaczmarczyk, P., Szczepański, M., \& Szulecka, M. (2010). The economy (labour market) as a primary driver of migrant inflow into Poland. In A. Górny, I. Grabowska-Lusińska, M. Lesińska, \& M. Okólski (Eds.), Immigration to Poland: Policy, employment, integration (pp. 91-148). Warszawa: Wydawnictwo Naukowe Scholar.

Grotte, M. (2012). Transfery dochodów ukraińskich migrantów [Financial remittances of Ukrainian migrants.] In Z. Brunarska, M. Grotte, \& M. Lesińska, Migracje obywateli Ukrainy do Polski w kontekście rozwoju społeczno-gospodarczego: stan obecny, polityka, transfery pieniężne (CMR WP 60/118). Warsaw: Centre of Migration Research, University of Warsaw.

Grzymała-Kazłowska, A., \& Okólski, M. (2003). Influx and integration of migrants in Poland in the early XXI century (CMR Working Papers 50). Warsaw: Institute for Social Studies, University of Warsaw. 
Hägerstrand, T. (1975). Space, time and human conditions. In A. Karlqvist, L. Lundqvist, \& F. Snickars (Eds.), Dynamic allocation of urban space (pp. 3-12). Lexington: Saxon House Lexington Book.

Hosnedlová, R., \& Stanek, M. (2010). Ukrainian migration to Spain: Sociodemographic profile, mobility patterns and migratory projects. In M. Baganha, J. Marques, \& P. Góis (Eds.), Imigraçãoucranianaem Portugal e no sul da Europa: aemergência de umaouváriascomunidades (pp. 211-230). Lisbon: Alto Comissariado para aImigração e Diálogo Intercultural.

Hosnedlová, R., \& Stanek, M. (2014). Analysing selected transnational activities among Ukrainian immigrants in Spain. Central and Eastern European Migration Review, 3(1), 99-114.

Iglicka, K. (1999). The economics of the petty trade on the Eastern Polish border. In K. Iglicka \& K. Sword (Eds.), The challenges of East-West migration (pp. 120-143). London: Palgrave Macmillan.

Iglicka, K., Gmaj, K., \& Borodzicz-Smoliński, W. (2011). Circular migration patterns. Migration between Poland and Ukraine. San Domenico di Fiesole: Metoikos Project.

Iglicka, K., \& Gmaj, K. (2013). Circular migration patterns between Ukraine and Poland. In A. Traindafyllidou (Ed.), Circular migration between Europe and its neighborhood: Choice or necessity? Oxford: Oxford University Press.

Illés, S., \& Kinces, Á. (2012). Hungary as receiving country for circulants. Hungarian Geographical Bulletin, 61(3), 197-218.

Janska, E., \& Drbohlav, D. (2008). The Czech Republic. In E. Honekopp \& H. Mattila (Eds.), Permanent or circular migration policy choices to address demographic decline and labour shortages in Europe. Hungary: IOM. Regional Mission for Central and South Eastern Europe.

Jaźwińska, E., \& Okólski, M. (Eds.) (1996). Causes and consequences of migration in Central and Eastern Europe. Podlasie and Ślask Opolski: basic trends in 1975-1994. Warsaw: Institute for Social Studies, University of Warsaw, Friedrich Ebert Stiftung.

Jaźwińska, E., \& Okólski, M. (Eds.). (2001). Ludzie na Huśtawce. Migracje między Peryferiami Polski a Zachodem [People on a swing. Migration between the Perypheries of Poland and the West]. Warszawa: Wydawnictwo Naukowe Scholar

Kaczmarczyk, P. (2002). Mobilność cyrkulacyjna jako kategoria badawcza w naukach społecznych [Circular mobilny as a research category in social sciences]. Studia Socjologiczne, 4, 37-66.

Kincses, Á., \& Rédei, N. (2009). Hungary at cross-roads. The Romanian Journal of European Studies, 7-8, 93-102.

Kindler, M. (2008). Risk and risk strategies in migration: Ukrainian domestic workers in Poland. In H. Lutz (Ed.), Migration and domestic work. UK: Ashgate.

Kindler, M. (2011). A risky business? Ukrainian migrant women in Warsaw's domestic work sector. Amsterdam: Amsterdam University Press.

Kindler, M., Kordasiewicz, A., \& Szulecka, M. (2015). Country profile. Ukraine-Poland. Global action programme on migrant domestic workers and their families. Geneva: ILO.

King, R., Thomson, M., Fielding, T., \& Warnes, T. (2006). Time, generations and gender in migration and settlement. In R. Penninx, M. Berger, \& K. Kraal (Eds.), The dynamics of international migration and settlement in Europe (pp. 233-267). Amsterdam: IMISCOE Joint Studies, Amsterdam University Press.

Kordasiewicz, A. (2010). Etniczny wymiar funkcjonowania rynku uslug domowych $w$ Warszawie [Ethnic dimension of care and domestic service market in Warsaw]. Warsaw: Institute for Public Affairs.

Kordasiewicz, A. (2011). Domestic service/servants. Transformation of asymmetrical social relation (PhD dissertation). Warsaw: University of Warsaw.

Leontiyeva, Y. (2014). The education-employment mismatch among Ukrainian migrants in the Czech Republic. Central and Eastern European Migration Review, 3(1), 63-84.

Levitt, P., DeWind, J., \& Vertovec, S. (2003). International perspectives on transnational migration: An introduction. International Migration Review, 3(37), 565-575.

Malmberg, G. (1997). Time and space in international migration. In T. Hammar, G. Brochmann, K. Tamas, \& T. Faist (Eds.), International migration, immobility and development, multidisciplinary perspectives (pp. 21-48). Oxford/New York: BERG. 
Malynovska, O. (2004). International labour migration from the Ukraine: The last 10 years. In M. I. Baganha \& M. L. Fonseca (Eds.), New waves: Migration from Eastern to Southern Europe (pp. 11-22). Lisbon: Luso-American Foundation.

Malynovska, O. (2011). Labour migration: Social consequences and political response. Kyiv: National Institute for Strategic Studies. http://www.niss.gov.ua/content/articles/files/Malin migraziya-dace3.pdf. Accessed 3 Sept 2015.

Mansoor, A. M., \& Quillin, B. (Eds.) (2006). Migration and remittances. Eastern Europe and the Former Soviet Union. Washington: The World Bank.

Massey, D. (1999). Why does migration occur? A theoretical synthesis. In C. Hirschman, P. Kasinitz \& J. DeWind (Eds.), The handbook of international migration. The American Experience (pp. 34-52). New York: Russell Sage Foundation.

Mitchell, C. (1961). The causes of labour migration, In: Migrant labour in Africa South of the Sahara (pp. 259-280). Abidjan: Commission for Technical Cooperation in Africa South of the Sahara.

Molodikova, I. (2008). Trends in the field of social policies and welfare reforms in Ukraine and Moldova. Centro Studi di Politica Internazionale http://www.cespi.it/WPMIG/BREPORT\%20 Ucraina.pdf. Accessed 2 Sept 2015.

Morokvasic, M. (2004). 'Settled in Mobility': Engendering post-wall migration in Europe. Feminist Review, 77, 7-25.

Näre, L. (2007). Ukrainian and Polish domestic workers in Naples - A case of East-South migration. Migration Online, http://www.migrationonline.cz/e-library/?x=1966763. Accessed 29 Jan 2014.

Newland, K., Aguinas,D.R., \& Terrazas, A. (2008). Learning by doing: Experiences of circular migration. MPI Insights. http://www.migrationpolicy.org/research/learning-doing-experiences-circular-migration. Accessed 5 Sept 2015.

Okólski, M. (1997). Najnowszy ruch wędrówkowy z Ukrainy do Polski [The newest mobility from Ukraine to Poland]. CMR Working Paper 14. Warsaw: Institute for Social Studies, University of Warsaw.

Okólski, M. (2001). Incomplete migration: A new form of mobility in Central and Eastern Europe. The case of Polish and Ukrainian migrants. In C. Wallace \& D. Stola (Eds.), Patterns of migration in Central Europe (pp. 105-128). New York: Palgrave.

Okólski, M. (2004). Migration patterns in Central and Eastern Europe on the eve of the European Union expansion. In A. Górny \& P. Ruspini (Eds.), Migration in the New Europe. East-West Revisited (pp. 23-48). Basingstoke: Palgrave Macmillan.

Piore, M. J. (1979). Birds of passage: Migrant labor and industrial societies. Cambridge: Cambridge University Press.

Piore, M. J. (1986). The shifting grounds of immigration. Annals of the American Academy of Political and Social Science, 485, 23-33.

Robertson, S. (2014). The temporalities of international migration: Implications for ethnographic research. ICS Occasional Paper Series 5(1), Sydney: Institute for Culture and Society.

Shakhno, S., \& Pool, C. (2005). Ukrainian migrants in the Netherlands. www.migrationonline.cz.

Solari, C. (2010). Resource drain vs. constitutive circularity: Comparing the gendered effects of Post-Soviet migration patterns in Ukraine. Anthropology of East Europe Review, 28(1), 215-238.

Stark, O., \& Bloom, D. E. (1985). The new economics of labor migration. American Economic Review, 75(2), 173-178.

Stola, D. (1997). Mechanizmy i uwarunkowania migracji zarobkowych do Polski [Mechanisms and conditions of labour migration to Poland]. CMR Working Papers 11. Warsaw: Institute for Social Studies, University of Warsaw.

Stola, D. (2001). Introduction: Patterns of migration in Central Europe. In C. Wallace \& D. Stola (Eds.), Patterns of migration in Central Europe (pp. 3-44). Basingstoke: Palgrave Macmillan.

Szulecka, M. (2007). Obecność cudzoziemców na targowisku zlokalizowanym wokót Stadionu Dziesięciolecia z perspektywy kryminologicznej [Foreigners' presence at the market located in 
the Warsaw Stadium area from criminological perspective]. CMR Working Papers 24(82). Warsaw: Centre of Migration Research, University of Warsaw.

Tolstokorova, A. V. (2010). Bitter berries of better life: Socio-demographic costs of labour migration for the Ukrainian society. ENQUIRE (Electronic Nottingham Quarterly for Ideas, Research and Evaluation), 5, 68-94.

Toruńczyk-Ruiz, S. (2014). Neighbourhood ties and migrant networks: The case of circular Ukrainian migrants in Warsaw, Poland. Central and Eastern European Migration Review, 3(1), 41-62.

Trevena, P. (2013). Why do highly educated migrants go for low-skilled jobs? A case study of Polish graduates working in London. In B. Glorius, I. Grabowska-Lusińska, \& A. Kuvik (Eds.), Mobility in transition. Migration patterns after EU enlargement. Amsterdam: Amsterdam University Press.

Triandafyllidou, A. (2011). Circular migration between the EU and its neighbours. A comparative analysis. BadiaFiesolana: European University Institute, Metoikos Project.

Triandafyllidou, A. (2013). Circular migration between Europe and its neighbourhood: Choice or necessity? Oxford: Oxford University Press.

UCSR, \& Ukrstat. (2009). Ukrainian external labour migration. Ukrainian Centre for Social Reforms. Kyiv: State Statistics of Ukraine.

Vertovec, S. (2007). Circular migration. The way forward in global policy? International Migration Institute, University of Oxford, Paper 4.

Vianello, F. A. (2011). Suspended migrants. Return migration to Ukraine. In M. Nowak \& M. Nowosielski (Eds.), (Post)trans-formational migration (pp. 251-274). Berlin: Peter Lang.

Vianello, F. A. (2013). A transnational double presence: Circular migrations between Ukraine and Italy. In A. Triandafyllidou (Ed.), Circular migration between Europe and its neighbourhood: Choice or necessity? (pp. 187-211). Oxford: Oxford University Press.

Wallace, D. (2001). The new migration space as a buffer zone? In C. Wallace \& D. Stola (Eds.), Patterns of migration in Central Europe. Basingstoke: Palgrave Macmillian.

Wallace, C. (2002). Opening and closing borders. Migration and mobility in East Central Europe. The Journal of Ethnic and Migration Studies, 28(4), 603-625.

Weber, S. (2004). Exploring some east-west migrant networks and their distant local dynamics, Ukrainian, Polish and Romanian migrants in Rome. In Maria I. Baganha \& M. L. Fonseca (Eds.), New waves: Migration from Eastern to Southern Europe. Lisbon: Luso-American Foundation.

Zelinsky, W. (1971). The hypothesis of the mobility transition. American Geographical Society, 61(2), 219-249.

Open Access This chapter is distributed under the terms of the Creative Commons AttributionNoncommercial 2.5 License (http://creativecommons.org/licenses/by-nc/2.5/) which permits any noncommercial use, distribution, and reproduction in any medium, provided the original author(s) and source are credited.

The images or other third party material in this chapter are included in the work's Creative Commons license, unless indicated otherwise in the credit line; if such material is not included in the work's Creative Commons license and the respective action is not permitted by statutory regulation, users will need to obtain permission from the license holder to duplicate, adapt or reproduce the material. 